\title{
Imaging Cold Spot
}

National Cancer Institute

\section{Source}

National Cancer Institute. Imaging Cold Spot. NCI Thesaurus. Code C94914.

A region of low activity within a larger region. 